\title{
Stop the Train
}

\section{YUANQING WANG}

A railroad wandered through the heart of the village like a gray, rusty river. It was a narrow gauge, built decades ago to ship coal out of the village and out of the mountains. When the coal was no more, the trains carried lemons; when it was not lemon-harvesting seasons, they carried people out and returned with empty carriages.

The children of the village used to play this silly game called stop the train. We would find a spot, a few hundred yards after where the railroad cut through a corner and where the conductor's line of sight, a bald man with a beer belly, would likely be hindered. We lay there, on the track, waiting for the train to come. When it did come, the kids, suddenly scared, would jump up and run from the track, one by one. The last one who stayed won. As if to challenge or to cheer, the train would whistle. But it never slowed down. Not even once.

Ms. L had ridden that train to the village two years ago, just when I started high school. It was a clear day in late September, when cool winds were just about to blow. The entire class, as well as the entire village, went to the station to greet her. We carried her coat and luggage and would have happily carried her if she would so indulge us.

The village had raised enough money to renovate a wooden barn house by the field, which had been used to store lemons, for Ms. L to stay in. They repainted the outside wall to be fire-brick red and installed new glass windows looking out to the misty mountains. Dried corns and peppers were hung on either side of the door as these, explained the villagers, signify harvest, abundance, and in general, good luck. Ms. L thanked the villagers for their good heart, directed them to put her luggage anywhere on the floor, and departed for the school. A sigh was let out on her way out, but not heard by anyone.

Upon entering the classroom in her mud-covered high heels, she wrote down her name with a tiny piece of chalk, the letter L whirling and flowing, making one forget the roughness of that mottled blackboard. She wore a white lace blouse and a skirt. The skirt was shorter than everyone else's in the village, revealing her fleshy thighs, which were about to get less fleshy and less smooth over time. The color of that skirt was vibrant with floral patterns of bright yellow, a contrast to the navy and olive drab green of our clothing.

In a soft, timid voice, she introduced herself. She told us that she had just received a master's degree in comparative literature from an institute named after a murderer, in some distant city that never sleeps. She also said that to teach English in the remotest part of her home country, where a grand revolution was ongoing, was the only way to make that degree somewhat useful.

"It's more than just a language that I'm trying to teach you," she said. "Once 
you know the language, you can read so much more."

During that first class, she talked about the history of the village that we had never heard, as if she had been here forever and we were the passersby. According to her, it was a group of missionaries who had brought the lemons. The villagers didn't like the missionaries; they called the dark-skinned ones monkeys and the pale-skinned ones ghosts. They killed and expelled them, as well as many of the new things the missionaries brought. Apart from the railroad, the lemons were the only thing that had survived. Magically, they bloomed in the lean soil that almost never grew anything, under the thick clouds that everlastingly shrouded the hills.

She stopped from time to time to write down English words that we might find unfamiliar: Missionary (noun) one who went on a mission to promote a religion;

Religion (noun) the belief in and worship of a superhuman controlling power; Capitalism (noun) a system based on the private ownership of the means of production.

She would have written down more big words, certainly, if she was aware of the fact that none of us in that classroom had ever tasted lemon, not properly. We didn't have lemon in our cuisine, and we didn't put lemon in our tea, nor did we know what a gin and tonic was. We had only consumed lemon in a way it shouldn't be, which was to eat it whole, unsliced, unpeeled, and unwashed, when it ripened and fell before the scheduled train and we couldn't bear the idea of watching it rot.

For months, everyone in the school was crazy about Ms. L's class. We entered the classroom long before the class started and familiarized ourselves with the chapters in the textbooks that she was scheduled to discuss. But she never talked a lot about the materials in the textbooks. She too often deviated from them to talk, in big and confusing words, about this movement or that, this group of activists or another, how they were no more than groups of cowards or hypocrites. She also spent a good deal of time recounting her life before she had entered the village. There was always an amazing spot at the corner of one numbered street and another, and she would spend her nights among other intellectuals hopping from cafes to bars to clubs, raising their glasses to the grand revolution, how they could and should devote themselves to it, with their feet and hands, not just shouting slogans at each other.

At this point, we, sons and daughters of the village, were lost. Some boys stared at her, but only to contemplate her slender figure, while others were ready to doze off. She never seemed to mind and always carried on.

I was perhaps the only one who had been constantly interested in her class. I loved all the details she gave about her previous life. Those details confirmed the existence of another world, a completely different world, outside these mountains. If I took this train, I told myself, and transferred to another train and another, I, too, theoretically, could reach that never-sleeping city, where 
everybody wore colorful short skirts.

Ms. L was always by herself. After class, she would head out of the school alone, warmly smiling at and nodding to someone's sister or aunt, but not participating in their small talks. What was there to talk about, anyway? The topics of conversation in this village were limited - the eternally sullen sky, the lemon trees under it, the everyday miseries among the villagers, and the sorrow, when the villagers waved goodbye to their children, one by one.

Of course, the village talked about Ms. L as well. The women wondered how L could have such a delicate waist and ankles smooth as pork lard. "Has she ever spent one day on a farm?" one would ask, but they couldn't comprehend or imagine, no matter how hard they tried, a life that didn't entail farm work and labor.

They also figured that none of the young men in the village would be good enough for her, not even the burliest young man in the production brigade who had wrestled an ox, not even the son of the head of the village council. Not even those two together, and the rest of the men as male concubines, taking turns by the calendar to take care of her, preparing her tea and washing her feet and all that. Not even that.

So she is going to leave, isn't she? Like all of them.

After about one year of her living in the village, she walked into the classroom in that same pair of mud-covered high heels and announced, rather seriously, that she was going to let the students in the class, or anybody in the village, freely borrow books from her. Since everybody had cheered, I was expecting a crowd in front of her doorstep, but it was just me. She didn't appear to be surprised or disappointed by this fact and proceeded to welcome me in. She wore a loose T-shirt that allowed me to see the contour of her small breasts and child-like nipples. "Would you like some hot water?" she asked, and I shook my head timidly.

The inside of the barn house looked emptier than when nobody had lived here. Much of the space was simply left untouched, and no furniture had been acquired except for the bamboo chair, table, and bed, which were all crippled in one way or another, that the village provided for her. With her suitcases laid on the ground containing volumes of books, it looked like she had either just unpacked or was about to leave tomorrow.

Without asking me which book I would like to read, she handed me How Steel was Tempered by Ostrovsky. "It's the first book every revolutionist should read," she said. As I thanked her and walked towards the door, she gripped my waist and asked me to stay. "So that I can know for sure that you understand every word," she said.

She asked me to sit after occupying the only chair in the room. I looked around. The cement floor seemed cold and damp. "You can sit on the bed," she looked at me and the bed, which squeaked as I carefully transferred my weight 
from my legs to it inch by inch.

And then I started reading the book to her, from "those of you who came to my house to be examined" to "he went back to Kiev where his work was awaiting him," word for word, all in one setting. She would stop from time to time to question me on the meaning of the words or to correct my pronunciation.

When I walked out of the barn house, it was already dark. The puddles on that muddy road were many and irregular. So, I gave up avoiding them and walked at my usual pace. Through the moonlight-permeated mist, I saw hundreds and thousands of tiny points, scattered through the lemon trees, shining, but very dimly. They were not lemons, I knew it all along. They were eyes. They were the eyes of the village.

Gradually, it became a habit-for two or three days a week - to go to Ms. L's barn house after class, where she would hand me a book without asking me to choose, and I would read it aloud to her. After Gorky it was Sholokhov. After Sholokhov it was Sartre. Before long I was reading The Eighteenth Brumaire of Louis Bonaparte with her quizzing me about the difference between a coup d'etat and a revolution.

When I got the answers right, she rewarded me, calling me a good kid. She would let me sit right next to her and explain to me what the characters would do after candles were blown out and curtains closed up, and what do weapons and houses, respectively, always mean in literature.

For a few moments, I forgot the age difference between us. We were just chatting - from big words and ideas, to her past, to the weather, the damning mists, and the harvest of the lemons. Before long, one could not tell our conversations from the small talks around the village she refused to participate in.

I told her about our game, stop the train, and she asked if I was a good player, to which I answered that I was not. I was always among the first to retreat.

"So, the train really never slowed down?" asked Ms. L.

"No, it really never slowed down."

Ms. L left the verse, "Let the tempest come strike harder" in large letters on the blackboard the day the villagers delivered the letter containing the order from the leader of the revolution that no teaching of foreign languages was allowed anymore. The same group who greeted her from the station two years ago escorted her, in total silence, to the train station.

In the meantime, I found myself lying on the train tracks, waiting for the train that would carry Ms. L away, to come. 